\title{
Microhardness, laser damage threshold and SHG efficiency studies of potassium dihydrogen phosphate crystals doped with L-arginine amino acid
}

\author{
E.I.Kostenyukova ${ }^{1}$, O.N.Bezkrovnaya ${ }^{1}$, M.I.Kolybaeva ${ }^{1}$, \\ E.F.Dolzhenkova ${ }^{1}$, N.O.Kovalenko ${ }^{1}$, A.Kanaev ${ }^{2}$ I.M.Pritula $^{1}$ \\ ${ }^{1}$ Institute for Single Crystals, STC "Institute for Single Crystals", National \\ Academy of Sciences of Ukraine, 60 Nauky Ave., 61001 Kharkiv, Ukraine \\ ${ }^{2}$ Laboratoire des Sciences des Prosedes et des Materiaux, CNRS, \\ 13 Universite Paris, Sorbone Paris Cite, France
}

Received January 12, 2016

\begin{abstract}
Potassium dihydrogen phosphate (KDP) single crystals doped with L-arginine (L-arg) amino acid (with a concentration of 0.3 to $1.4 \mathrm{wt}$. $\%$ in the solution) were grown onto a point seed by the temperature reduction method. The effect of L-arg molecules on the strength properties $\{100\}$ of KDP crystal were studied. Doping of KDP crystals with L-arg molecules raised the laser damage threshold in comparison with pure KDP in the sector $\{101\}$. There were defined the ranges of L-arg concentration where the microhardness and bulk laser damage threshold of KDP:L-arg crystals were higher in the growth sectors as compared with pure KDP. It was found that the efficiency of second harmonic generation in KDP:L-arg (1.4 wt.\% of L-arg) exceeded the corresponding characteristic of pure KDP by 2.5 times.

Keywords: L-arginine amino acid, microhardness, laser damage threshold, second harmonic generation.

Методом снижения температуры на точечной затравке выращены монокристаллы дигидрофосфата калия (KDP), допированные аминокислотой L-arginine (L-arg, с концентрацией 0.3-1.4 мас. \% в растворе). Исследовано влияние молекул L-arg на прочностные свойства кристаллов KDP $\{101\}$. Допирование кристаллов KDP молекулами L-arg привело к увеличению порога лазерного разрушения по сравнению с чистым KDP в секторе $\{101\}$. Определены интервалы концентраций L-arg, при которых микротвердость и объемная лазерная прочность кристаллов KDP:L-arg возрастает по сравнению с чистым KDP. Установлено, что эффективность генерации второй гармоники в кристалле KDP:L-arg (1.4 масc.\% L-arg) в 2.5 раза больше, чем в чистом кристалле KDP.
\end{abstract}

Дослідження мікротвердісті по Віккерсу, лазерного руйнування та ефективності генерації другої гармоніки кристалів KDP з домішкою L-аргініну. O.I.Костенюкова, О.М.Безкровна, М.І.Колибаєва, Е.Ф.Долженкова, Н.О.Коваленко, А.Канаєв, І.М.Притула.

Методом зниження температури на точковій затравці вирощено монокристали дигідрофосфату калію (KDP), допованого амінокислотою L-arginine (L-arg, з концентрацією 0,3-1,4 мас.\% в розчині). Досліджено вплив молекул L-arg на міцнісні властивості кристалів KDP \{101\}. Допування кристалів KDP молекулами L-arg призвело до збільшення порогу лазерного руйнування у порівнянні з чистим KDP в секторі $\{101\}$. Визначено інтервали концентрацій L-arg, при яких мікротвердість і об'ємна лазерна міцність кристалів KDP:L-arg вище у відповідних секторах росту порівняно з чистим 
KDP. Встановлено, що в кристалі KDP:L-arg (1,4 мас. \% L-arg) ефективність генерації другої гармоніки в 2,5 рази більше, ніж у чистому кристалі KDP.

\section{Introduction}

One of the problems for up-to-date materials science is creation and investigation of nonlinear optical composite materials based on inorganic matrices such as KDP $\left(\mathrm{KH}_{2} \mathrm{PO}_{4}\right)$ group crystals. Optical elements manufactured from these crystals are widely used in optoelectronics in the capacity of frequency converters, optical switches and laser radiation limiters, new memory elements, active laser media, etc.

KDP group crystals possess high structure perfection, mechanical strength, wide range of spectral transparency, as well as relatively high values of laser damage threshold. Moreover, the growth technology makes it possible to obtain KDP crystals with well-developed growth sectors containing practically no defects. Nevertheless, relatively low value of quadratic susceptibility is one of the main functional restrictions for the use of KDP crystals. In the case of noncentrosymmetric bonds in the structure of the crystal the value of general quadric optical susceptibility may be essentially influenced by the hydrogen bonds between the structure units of the crystal. The contribution of the hydrogen bonds to the value of the efficiency of the second harmonic generation (SHG) for KDP group crystals is widely discussed in the literature $[1,2]$. It has been shown that the nonlinear optical (NLO) characteristics of KDP can be controlled due to increase of the number of the hydrogen bonds in the crystals and optimization of their spatial arrangement $[3,4]$.

Actively used for raising NLO response in KDP crystals is their doping with different organic molecules which possess high polarizability and contain the groups which can effectively form hydrogen bonds with the growing crystal face. Such organic molecules comprise dyes e.g. xylene orange [5], urea [6] and amino acids [5-8]. The amino acid molecules have high polarizability due to the processes of internal charge transfer between the donor $\left(\mathrm{COO}^{-}\right.$and acceptor $\left(\mathrm{NH}_{2}{ }^{+}\right)$groups [5-6, 8]. ADP:L-alanine crystals show the rise of the efficiency of SHG by a factor of 1.75 , whereas the introduction of glycine molecules into KDP crystals increases such an efficiency by a factor of $\sim 1.3$ with respect to the one of pure KDP [9]. The doping of KDP crystals with L-arginine (L-arg), as well as with L- valine and L-threonine amino acids leads to the rise of the NLO coefficients by $1.33-1.74$ and $\sim 1.1$ times, respectively, in comparison with that of the pure crystal [9-12]. On the other hand, the organic ligands L-Proline and L-Methionine negatively influence the NLO properties of KDP group crystals $[13,14]$.

In view of the above-said, the studies of the influence of amino acid molecules on the strength and NLO properties of the heterogeneous system based on KDP crystal are undoubtedly topical. The choice of L-arg amino acid as a modifying dopant is caused by the fact that it contains the amino group with a strong electron acceptor property which may essentially influence the electron density distribution in the molecule and, consequently, the value of NLO response [15, 16].

\section{Experimental}

\subsection{Crystal growth}

Nominally pure KDP single crystals and the ones with incorporated L-arginine amino acid were grown by the temperature reduction method, as reported in [17], onto $5 \times 5 \times 10 \mathrm{~mm}^{3}$ point seed. The mother liquors $(\mathrm{pH}=4.0 \pm 0.1)$ were prepared in correspondence with the curve of solubility at the saturation temperature $50.9^{\circ} \mathrm{C}$. KDP:L-arg crystals were grown from the mother liquors with concentrations of L-arg with respect to KDP salt of $0,0.3,0.4,1$ and 1.4 wt. $\%$. The solutions were filtered and then overheated during $24 \mathrm{~h}$ at $T=80^{\circ} \mathrm{C}$. The relative solution supersaturation $\sigma$ was $\sim 2 \%$, the rate of temperature reduction being $0.3^{\circ} \mathrm{C} /$ day. To provide dynamic crystal growth conditions, the solution in the crystallizer was stirred at a rate of $70 \mathrm{rpm}$. The average rate of the growth of the doped crystals along the growth directions was $V_{z}$ $=2.0 \mathrm{~mm} /$ day and $V_{x, y}=1.3 \mathrm{~mm} /$ day. All the grown crystals had well-developed growth sectors $\{100\}$ and $\{101\}$. The samples to be investigated were cut out from both crystal growth sectors.

2.2. Laser induced damage threshold measurements

The samples were subjected to the action of single-mode pulsed radiation of $\mathrm{Nd}: \mathrm{YAG}^{3+}$ laser at the wavelength $\lambda=1.064 \mu \mathrm{m}$ with an energy of $2.75 \mathrm{~mJ}$, the pulse repetition frequency and the pulse duration were $1 \mathrm{~Hz}$ 
and $\tau=10 \mathrm{~ns}$, respectively. The 1 /e-radius of the focused spot was estimated to be $45 \mu \mathrm{m}$. The investigated samples were arranged in such a way that the focus of the optical system lays in the crystal bulk. The samples were irradiated at each point according to the scheme n-1-n (90 pulses at the same energy, the samples were moved in the plane perpendicular to the laser beam). The criterion of laser damage was visually observed sparks of high-temperature plasma in the sample bulk. The laser damage threshold of KDP and KDP:L-arg crystals was studied in the directions [100] and [001].

\subsection{Microhardness measurements}

The mechanical strength of KDP and KDP:L-arg crystals was measured using a PMT-3 device by the method of concentrated load on the faces (001) and (100). The investigated samples were preliminarily treated by mechanical grinding and polishing. The indentation load was in the range 0.2-2 $\mathrm{N}$; the typical descent rate of indenter was $\sim 1 \mathrm{~mm} / \mathrm{min}$, and each load was applied for $10 \mathrm{sec}$. To avoid overlapping of the regions of surface stress formed around the neighbouring indenter imprints, the distance between the imprints was larger than the length of the imprint diagonal by 10 times. The dimensions of the imprint diagonals $(d)$ were measured by an optical microscope. The microhardness value was calculated from the standard equation:

$$
H v=\frac{k \cdot P}{d^{2}},
$$

where $k$ is the geometrical conversion factor (equal to 1.854 for the Vickers indenter). The average microhardness value was calculated for each sample on the base of 10 imprints on the faces (100) and (001).

\subsection{SHG measurements}

The efficiency of SHG in KDP and KDP:L-arg crystals was studied on a special laboratory setup. Pulsed laser radiation was generated using a solid-state laser LOTI-3 with Nd:YAG active element. The pumping pulse energy was $\sim 100 \mathrm{~mJ}$ at a duration of $\sim 10 \mathrm{~ns}$. For compensation of the pumping radiation divergence there was used an optical system which comprised spherical and cylindrical lenses. The emitted light passed through a light filter transparent to the second harmonic radiation and absorbing the pumping radiation. The samples of "pure" and doped crystals were cut out at the angle of phase matching $\theta=59^{\circ}$, that corresponded to the synchronism type $o e-e$. The experiment was repeated at different input powers, and the corresponding output power was measured. The SHG efficiency was obtained from the ratio of the output energy of the second harmonic to the input power of the pumping pulses.

\section{Results and discussion}

As shown in our earlier paper [15], L-arg molecules are incorporated into the prismatic and pyramidal growth sectors of KDP crystals obtained from the solution containing $~ 1.4$ wt. $\%$ of L-arg. Thereat, L-arg molecules enter into the growth sector $\{100\}$ due to the fact that their structure contains carboxyl and amino groups which can form hydrogen bonds with the face (100) of the growth sector $\{100\}$; their incorporation into the sector $\{101\}$ is provided by the electrostatic interaction between the negatively charged groups $\mathrm{COO}^{-}$and the positively charged face (101).

In the present study we measured for the first time the bulk laser damage threshold of a series of the samples of KDP crystals obtained from the growth sectors $\{100\}$ and \{101\} and containing $0.3-1.4$ wt. \% of L-arg. The average values of bulk laser damage threshold for the pure and doped crystals measured in the directions [001] and [100] in the growth sectors $\{100\}$ and $\{101\}$ are presented in Table 1. As is seen, in the pure and doped crystals the probability of damage in the direction [100] is higher than the one in the direction [001]. Due to the introduction of L-arg molecules into the matrix of the sector $\{101\}$ the laser damage threshold of the crystal in the directions [100] and [001] becomes higher in comparison with that of pure KDP. For the sector $\{101\}$ the introduction of the amino acid leads to the increase of the laser damage threshold in the directions [100] and [001] by $33 \%$ and $25 \%$, respectively, in comparison with the corresponding value for pure KDP (at $1.4 \mathrm{wt}$. $\%$ content of L-arg). This agrees with the data reported in $[18,19]$.

The microhardness measurements performed for KDP:L-arg and pure KDP crystals show that at loads of $0.2-2 \mathrm{~N}$ all the samples show "reverse indentation size effect" connected with the influence of the surface crystal layer which is most essential at low indenter loads [20] (Fig.hardness at loads of 0.5 to $2 \mathrm{~N}$ does not depend on the load and makes 1.85-1.9 GPa for the planes (100) and (001) for the sector $\{101\}$ and 
Table 1. Laser damage threshold of KDP and KDP:L-arg crystals

\begin{tabular}{|c|c|c|c|c||}
\hline \multirow{2}{*}{$\begin{array}{c}\text { L-arg concentration } \\
\text { in the mother } \\
\text { liquor, wt. } \%\end{array}$} & \multicolumn{2}{|c|}{ Sector $\{101\}$} & \multicolumn{2}{c|}{ Sector $\{100\}$} \\
\cline { 2 - 5 } & $(001) \mathrm{J} / \mathrm{cm}^{2}$ & $(100) \mathrm{J} / \mathrm{cm}^{2}$ & $(001) \mathrm{J} / \mathrm{cm}^{2}$ & $(100) \mathrm{J} / \mathrm{cm}^{2}$ \\
0.3 & 42.1 & 28.62 & 42.1 & 37.42 \\
0.4 & 21.67 & 19.5 & 37.76 & 33.4 \\
1.4 & 61.87 & 38.52 & 33.4 & 34.85 \\
\hline
\end{tabular}

Table 2. Microhardness of KDP and KDP:L-arg crystals at indenter load $P=75 \mathrm{~g}$

\begin{tabular}{|c|c|c|c|c|}
\hline \multirow{2}{*}{$\begin{array}{l}\text { L-arg concentration } \\
\text { in the mother } \\
\text { liquor, wt. } \%\end{array}$} & \multicolumn{2}{|c|}{ Sector $\{101\}$} & \multicolumn{2}{|c|}{ Sector $\{100\}$} \\
\hline & (001), GPa & $(100), \mathrm{GPa}$ & (001), GPa & (100), GPa \\
\hline 0 & 1.97 & 1.93 & 2.17 & 2.06 \\
\hline 0.3 & 2.25 & 2.17 & 2.22 & 2.093 \\
\hline 0.4 & 2.129 & 2.074 & 2.121 & 2.047 \\
\hline 1.0 & 2.021 & 1.935 & 2.068 & 1.895 \\
\hline 1.4 & 1.77 & 1.870 & 1.870 & 1.720 \\
\hline
\end{tabular}

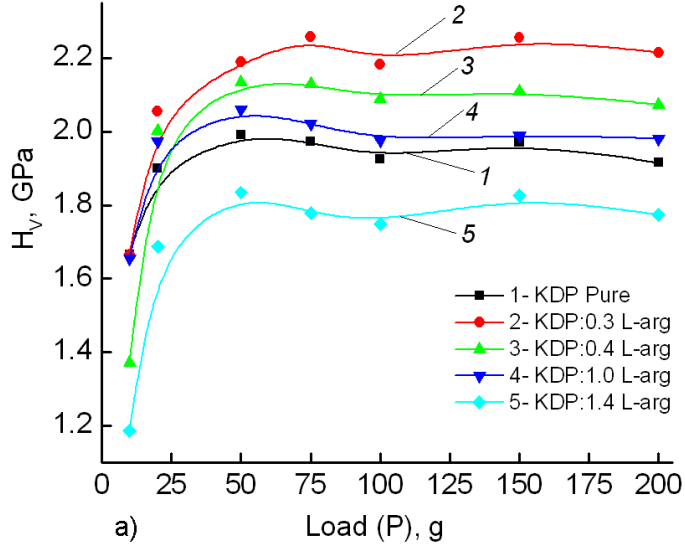

Fig. Plots of $H_{\mathrm{V}}$ load the plane (001) for sectors crystals.

2.0-2.15 GPa for the sector $\{100\}$ (Table 2). It has been found that at $0.3-1.0 \mathrm{wt}$. $\%$ concentration of L-arg the microhardness value $H_{\mathrm{V}}$ in the sector $\{101\}$ increases in comparison with the one of pure KDP. The rise of the mechanical strength of the crystals result in from their doping may be bound up either with changes in the crystal structure or with a decrease of the mobility of point and linear defects. With the increase of the concentration of L-arg to 1.4 wt. \% the microhardness of both crystal faces diminishes by $\sim 5-9 \%$ and $\sim 14-$ $18 \%$ for the sectors $\{101\}$ and $\{100\}$, respectively. This is caused by disturbance of the crystal structure due to the entering of much larger quantity of L-arg molecules into the crystal. Similar diminution of the

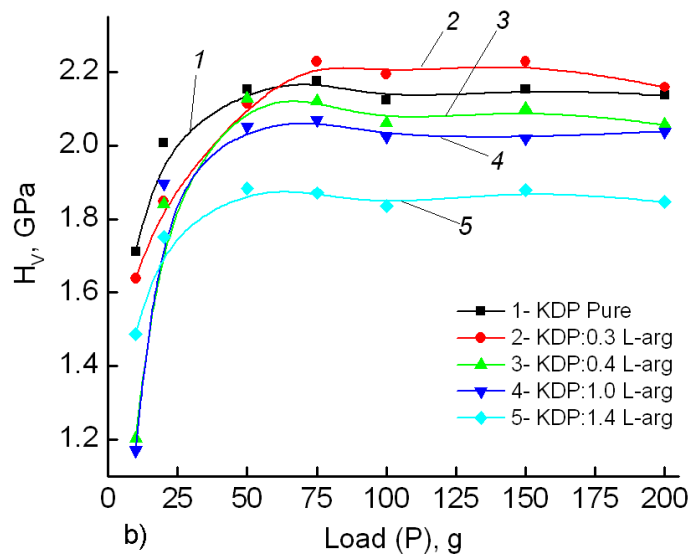

(a) and $\{100\}$ (b) KDP and KDP:L-arg value of microhardness in KDP crystals was observed at their doping with the amino acids L-histidine, L-threonien and DLmethionine [13].

At loads of $0.5-2 \mathrm{~N}$ the value of microhardness in the doped crystals rises in the direction [001] in comparison with the one in the direction [100]. Such a change has been also reported in [21] for urine-doped KDP crystal. This is explained by the fact that the process of deformation of the surface (100) involves a larger quantity of slip systems than it takes place for the surface (001). Therefore, the degree of hardening of these two surfaces is different [3, 21]. As a result, the probability of both laser and mechanical damage in the direction [100] is higher. 
Table 3. Efficiency of SHG in KDP and KDP:L-arg at different L-arg concentrations

\begin{tabular}{|c|c|c||}
\hline $\begin{array}{c}\text { L-arg concentration } \\
\text { in the mother } \\
\text { liquor, wt. } \%\end{array}$ & Sector $\{101\}$ & Sector $\{100\}$ \\
\hline 0 & 1 & 1 \\
0.3 & 1.33 & 2.36 \\
1.0 & 1.5 & 2.92 \\
1.4 & 2.53 & 3.95 \\
\hline
\end{tabular}

Investigation of the NLO properties of KDP and KDP:L-arg shows that in the samples of the doped crystals the efficiency of SHG is higher in comparison with that in the pure crystals (Table 3 ). With the rise of the concentration of L-arg molecules the radiation conversion intensity increases, too. Thereat, the efficiency of SHG grows proportionally to the rise of the concentration of L-arg in the crystal.

As is known, the main contribution to the quadratic NLO response of KDP crystal is made by the group $\mathrm{PO}_{4}^{3-}$ [22] and the presence of hydrogen bonds [23]. It seems possible that the incorporation of L-arg molecules into the matrix of KDP is accompanied with an additional deformation of the tetrahedrons $\mathrm{PO}_{4}$ due to the formation of hydrogen bonds between L-arg amino group and the group $\mathrm{H}_{2} \mathrm{PO}_{4}^{-}$of KDP crystal that leads to local distortion of the matrix lattice and the appearance of the corresponding polarization. The efficiency of SHG of KDP:L-arg crystals may be also caused by the contribution of nonlinear polarizability of Larg molecules due to intramolecular charge transfer. Though L-arg molecules do not contain extensive systems of $\pi$-bonds, they possess intromolecular charge transfer with participation of orbitals of the donor and acceptor groups in the transitions. Excitation of L-arg molecules gives rise to charge redistribution between the donor and acceptor that may be accompanied with essential increase of the dipole moment of the molecule.

\section{Conclusions}

KDP and KDP:L-arg crystals (with 0.31.4 wt. $\%$ concentrations of L-arg in the mother liquor) were grown by the method of temperature reduction. The doped KDP crystals were found to possess higher bulk laser damage threshold in the sector $\{101\}$ in comparison with pure KDP. In KDP:Larg containing 0.3 wt. \% (the sector $\{100\}$ ) and $0.3-1$ wt. \% of L-arg (the sector $\{101\}$ ) the value of microhardness increased. At further rise of the concentration of L-arg the microhardness of the faces (100) and (101), as well as of two crystal growth sectors diminished due to weakening of the bonding strength between the atoms in KDP:L-arg crystal lattice caused by entering of a large quantity of the organic molecules. For KDP:L-arg (1.4 wt. \% of L-arg) crystals the efficiency of SHG exceeded the one of pure KDP by $\sim 2.5$ times.

Acknowledgment. The authors are grateful to A.K.Kapustnik (Institute for Single Crystals) for his help in measurements of the SHG efficiency.

\section{References}

1. D.Xue, S.Zhang, J.Chem.Phys.Lett., 301, 449 (1999).

2. D.Xue, S.Zhang, J.Phys. B, 262, 78 (1999).

3. I.Pritula, A.Kosinova, M.Kolybayeva et al., $J$. Mater. Res. Bull., 43, 2778 (2008).

4. D.Xue, S.Zhang, J.Phys.Chem.A, 101, 5547 (1997).

5. I.Pritula, V.Gayvoronsky, Yu.Gromov et al., J.Opt.Commun., 282, 1141 (2009).

6. I.Pritula, A.Kosinova, M.Kolybayeva et al., Functional Materials, 14, 295 (2007).

7. K.Wu, C.Liu, C.Mang, J.Opt.Mater., 29, 1129 (2007).

8. I.M.Pritula, Y.N.Velikhov, Proc.SPIE, 3793, 202 (1999).

9. K.D.Parikh, D.J.Dave, B.B. Parekh et al., J. Bull. Mater. Science, 30, 105 (2007).

10. J.Zyss, G.Berthier, J.Chem.Phys., 71, 75 (1979).

11. P.Kumaresan, S.Moorthy Babu, P.M.Anbarasan, J.Opt. Mater., 30, 1361 (2007).

12. D.J.Dave, K.D.Parikh, B.B.Parekh et al., J. Optoelectron.Advance Mater., 11, 602 (2009).

13. D.J.Dave, K.D.Parikh, M.J.Joshi, J.Advanc. Mater. Res., 665, 172 (2013).

14. P.Jagdish, N.P.Rajesh, J.Optoelectron.Advance Mater., 13, 962 (2011).

15. J.Govani, W.Durrer, M.Manciu et al., $J$. Mater. Res., 24, 2316. (2009).

16. M.Mena, C.Mahadevan, J.Cryst.Res.Technol., 43, 166 (2008).

17. E.I.Kostenyukova, O.N.Bezkrovnaya, V.F.Tkachenko, Functional Materials, 22, 309 (2015).

18. D.Xu, D.Xue, J.Cryst.Growth, 286108 (2006).

19. I.M.Pritula, V.I.Salo, M.I.Kolybaeva, Inorg. Mater., 37184 (2001).

20. K.Sangwal, J. Mater. Chem. Phys., 63, 145 (2000).

21. A.V.Kosinova, M.I.Kolybaeva, O.N.Bezkrovnaya et al., J.Cryst. Res., 49, 965 (2014).

22. Zh.Lin, Zh.Wang, Ch.Chen et al., J.Chem. Phys., 118, 2349 (2003).

23. R.Ledzion, P.Gorski, W.Kucharczyk, J.Phys. Chem. Solid., 68, 1965 (2007). 